Ladynenko A. P., PhD in Philology, Associate Professor at the Foreign Languages Department No. 2 National University "Odessa Academy of Law"

\title{
ETHNONYMS IN THE PLAYS BY WILLIAM SHAKESPEARE
}

Summary. The article deals with the ethnonymic usages in Shakespeare's plays. The illustrations were taken from the following plays: Cymbeline, Hamlet, Henry VI (part I), King Lear, Othello, Merry Wives of Windsor presented in the form given in the Wordsworth Collection (2007). It is explained that ethnonyms are words that indicate the nationality and belonging to ethnoses of different sizes and different places of settlement. It is suggested that ethnonyms should be grouped in the primary ethnonyms - official names established in the international and linguistic practice and the secondary ones - non-official names and nicknames of ethnic groups and unities.

Shakespeare is not inclined to invent ethnonyms, he draws them from the existing word stock. He uses ethnophobisms mostly in the scenes where conflicts are likely to arouse. Regards to the secondary ethnonyms one can state that in Shakespeare's plays pejorative units ethnophobisms are predominant. Shakespeare uses both official and non-official ethnonyms denoting representatives of great ethnic groups (races, nations) and small ethnic groups including residents of cities and towns (demonyms). Ethnonyms in Shakespeare's plays fulfill two main functions: in some cases, they are indicators of ethnic identification of the individual, and in some other cases they characterize personages due to the national stereotypes. It was noted that it is not always clear whether Shakespeare uses the ethnonym in its nominative function (the marker of nationality) or in the characterological one. Such is the case of the ethnonym "Florentine" when it concerns Jago (Othello). The phrase "I never knew a Florentine more kind and honest" can be treated in both ways.

The investigation shows that Shakespeare wasn't accurate in his choice of ethnonyms so there are many anachronisms in his plays. For example, in the times of Lear described by Shakespeare the ethnonym "Englishman" did not exist. In fact, Shakespeare is not to blame, because some editors and stage directors replaced his "British man" by the word "Englishman". Ethnic anachronisms can be found in his "Cymbeline". One of personages is denoted as "Frenchman". In the times of Cymbeline France as a state did not exist. The investigation showed that in many cases Shakespeare modernized the events carrying over the representatives of some groups to the ancient times when they did not exist.

The artistic ethnonymic field of Shakespeare required further deep investigation. The comparison of ethnonymic variants in different folios and modern editions will allow to distinguish between the original versions of Shakespeare and corrections made by the editors.

Key words: demonym, endoethnonym, ethnic anachronism, ethnonym, ethnophobism, exoethnonym, William Shakespeare.
Introduction. The article deals with the ethnonymic usages in Shakespeare's plays. The ethnonymic problems were never in the center of scholars who study the idiostyle of Shakespeare. There is not any special work devoted to the ethnonymic sub-systems of the Shakespearean word-stock and the functions of ethnonyms in his artistic picture of the world. Separate aspects of the problem are touched upon in Asimov's "Guide to Shakespeare" [1], but they are not systematized.

In the process of the investigation such methods as direct observation, corpus units' collection and interpretative approach as well as quantitative analysis were used. The ethnocultural and historical sources were widely used for more accurate explanation and treatment $[2 ; 3 ; 4 ; 5 ; 6 ; 7 ; 8 ;$ etc. $]$ of the ethnonymic usage in some of Shakespeare's plays.

The illustrations were taken from the following plays by Shakespeare: Cymbeline, Hamlet, Henry VI (Part I), King Lear, Othello, Merry Wives of Windsor presented in the form given in the Wordsworth Collection [9].

The aim of the paper is to single out the peculiarities of the ethnonymic field of the plays by Shakespeare.

Ethnonyms are words that indicate the nationality and belonging to ethnoses of different sizes and different places of settlement. Ethnonyms are divided into endoethnonyms (autoethnonyms), that is self-names of the ethnic units and exoethnonyms (aloethnonyms), that is names of ethnoses which are given to them by representation of other ethnoses. We suggest that all the ethnonyms should be grouped in the primary ethnonyms - official names established in the international and linguistic practice and the secondary ones non-official names and nicknames of different ethnic groups and unities. Many secondary ethnonyms can be called ethnophobisms as they have a negative colouring and are used as obscene words (e.g. "Fritz" instead of the German; "dustbin-lids" instead of the Jews, etc.).

Some authors such as Swift, Pelevin coined new words including ethnonyms, especially when the subject is fantastic and the story is set in the surrealistic world. As it is known Swift coined such ethnonyms as Lilliputians, Yahoos, the Honyhnhnms, etc. in his famous story of Gulliver. Shakespeare is not inclined to invent new ethnonyms. He draws them from the existing word-stock but often ignoring their ethymology and time of their fixation in the English language.

Shakespeare resorts to the ethnophobisms mostly in the scenes where there arouse conflicts and quarrels. Among the invective units then appear offensive words in which ethnic aspects are touched upon. 
The quantative analysis shows that among the secondary ethnonyms engaged in the plays by Shakespeare predominant are the pejorative units (87\%). One can hardly encounter secondary ethnonyms used in the plays by Shakespeare as meliorative characteristics of the personages.

Main results. Ethnonyms have different functions. They are used as units that denote nationality or indicate the birth place of residence (Athenean) of the subject nominated. But they also fulfil characterological functions, emphasizing different qualities and features of the person mentioned. The phrase "Nick is a real German" shows that Nick (if he is not an ethnic German but an Englishman) has those qualities which are ascribed to the German people (accuracy, discipline, punctuality) due to certain stereotypes which were formed for centuries, though particular persons (individuals) of German origin may deviate from this standard [10, p. 189].

Up to the recent times there was not a separate term for citizens of the cities and towns. The general terms "ethnonym" or "topo-ethnonym" were used. But the topo-ethnonym applies to the residents of various localities (places) - countries, regions, cities, villages, etc.

We decided to use the terms "city demonyms" or "town demonyms" for the words which denote residents of the corresponding above-mentioned units (cities and towns). The term is borrowed from the Merriam-Webster editor Paul Dickson (1988). But Dickson used it in a broad sense including residents of different localities (countries, administrative units of different sizes cities, etc.). In our case its meaning is reduced to the residents of the cities and towns.

Thus, Athenian is a city demonym denoting a citizen of Athens, Parisian - a city demonym denoting a citizen of Paris. The general term "ethnonym" we shall use when referring to the residents of the countries.

Our analysis shows that Shakespeare uses different ethnonyms in his plays. The investigation also shows that the nomenclature of the ethnonyms employed in the XVI-XVII c. (the Elizabethan times) does not coincide with that of Modern English.

Shakespeare uses both official and non-official ethnonyms denoting representatives of great ethnic groups (races, nations) and small ethnic groups including residents of cities and towns (demonyms).

The ethnonyms in his works fulfil different functions. They are indicators of ethnic identification of the individual (nationality, place of birth or place of residence). They also help to characterize individuals due to the national stereotypes irrespective of his or her real nationality. The term "transferred characterological ethnonym" can be used here if a person belongs to the nationality other than that on which the stereotype is based.

Our analysis also testifies to the fact that Shakespeare was not accurate in his choice of the ethnonyms. Often he ignores the historical and temporal factors and it brings about the appearance of many anachronisms, that is ethnonyms which could hardly be used in the times depicted in his plays (e.g. Scythians in his "King Lear"). His main aim was to make his works understandable for the audience, his contemporaries. He did not care much for the political correctness using the offensive secondary ethnonyms (ethnophobisms) ignoring the feelings of foreigners and trying to pander to the low tastes of the audience. In the times of Lear described by Shakespeare the ethnonym "Englishman" did not exist. It appeared only after the invasion of the Anglo-Saxons on the British Isles in the V c. AD.
When Shakespeare uses the ethnonym "British man" it does not sound as an anachronism:

Edgar. Child Roland to the dark tower came.

His word was still 'Fie, for, and fum.

I smell the blood of a British man'

[King Lear, Act III, Scene 4, lines 175-177].

But some editors and stage directors "corrected" Shakespeare and replaced the ethnonym "British man" by the word "Englishman". This "correction" leads to the appearance in the text of the anachronisms which can hardly be justified. In this case Shakespeare is not to blame.

But there are some cases when Shakespeare is not consistent in his approach to the ethnonyms usage in terms of their time reference. In the following fragment Oswald exclaims before his death:

Oswald. Slave, thou hast slain me. Villain, take my purse:

If ever thou wilt thrive, bury my body,

And give the letters which thou find'st about me

To Edmund Earl of Gloucester, seek him out

Upon the English party. O, untimely, death! Death!

[King Lear, Act III, Scene 4, lines 246-249].

In this episode Shakespeare uses the adjective "English" which can be qualified here only as an anachronism [11].

We should remind the reader that in the epoch described by Shakespeare in his "King Lear", the notions "English" and "Englishman" did not exist. The ethnonym "Englishman" appeared in the word-stock only in thirteen centuries after the events described in the "King Lear" [1, p. 50].

In the above-mentioned version of this fragment J. Heminge and H. Condell did not correct Shakespeare. They did not substitute the word "English" for the word "British". The former can be found in the earlier folios, in which Shakespearian original, as a rule, was preserved. Thus, the original Shakespearean variant (the English Party), that is the anachronism, remained untouched in the Wordsworth Library Collection.

Ethnic anachronisms can be found in his "Cymbeline". In the list of personages, one can encounter the characters denoted as "Frenchman". In the times of Cymbeline (5-40 AD) France as a state did not exist. Nor existed the community consisting of the Frenchmen. In the author's note to one of the scenes it is said that a Dutchman and a Spaniard are also participants to the action:

Act III. Scene IV.

Rome. Philario's house.

Enter Philario, Iachimo, a Frenchman,

A Dutchman, and a Spaniard.

[Cymbeline, Act I, Scene 4, lines 1-3].

The presence of the Spaniard is possible if to consider him a representative of the Celtic tribes, who settled in the peninsula which the Romans called Spain. But the figure of the Dutchman arouses doubts as the nation of Dutchmen (as well as the country the Netherlands) formed much later.

All the utterances of the Frenchman about Orlean also sound strange. Shakespeare modernized the action including the personages of the countries which did not exist in the times described.

In the XVI c. there was an endoethnonym "Osman" for the Turkish people while the Slavonic and other peoples used the exoethnonym "Turk". The word "Turk" was the endoethnonym for the peasants of the Osman Empire while the citizens of the cities called themselves Muslims, that is they used the religious indicator in the meaning of the superethnonym (ethnonym which embraces 
the representatives of several nations united by their beliefs and traditions).

The Turk in the times of Shakespeare was a symbol of unlimited voluptuousness. Shakespeare applied this ethnic stereotype in the characterological function. When Lear asks Edgar about his past, the latter repents of his sins:

Lear. What hast thou been?

Edgar. A serviceman, proud in heart and mind (...) and in woman out-paramour'd the Turk.

[King Lear, Act III, Scene 4, line 111].

Edgar uses the ethnonym "Turk" to emphasize the degree of his own passion for women. But this ethnonym is an anachronism as the people who were called by this name appeared on the ethnic arena only in sixteen centuries after the epoch of legendary King Lear.

But in the times of Shakespeare there was formed and established the stereotype according to which a Turk is a voluptuous person who does not know any limits.

This impression was enforced by the fact that the Turkish sultan had an enormous harem and he himself was a man of great passion. This vivid image was well-known by audience in the Elizabethan theatre (XVI-XVII c.) and was accepted as a justified means of expression.

The mentioning of the Swiss (Switzers) as guards in the times depicted by Shakespeare in his "Hamlet" is a pure anachronism: Switzerland did not exist as a state at that time. Nor did exist the nation called the Swiss. Only in 1291 there was formed a federation which became the basis of the state which in English is called Switzerland and in German - Schwiz with the corresponding ethnonyms "Swiss/Switzer".

The demand for the Swiss warriors as reliable guards became great in Europe after a number of victories over Charles of Burgundy whom they destroyed in three battles (XV c.).

There was a custom among the kings to invite the Swiss mercenaries (free lancers) as personal body guards. They were incorruptible and defended up to the very end those who officially paid for their services even when the resistance was hopeless as was the case with the King Louise XVI during the revolution in France.

The King Claudio from the "Hamlet" who is afraid of the murder attempt after he killed his brother, constantly feels trouble and starts at every strange sound or noise. He hopes that the Swiss guards will defend him:

King (calls). Attend!

Where are my Switzers? Let them guard the door.

[Hamlet, Act VI, Scene 5, lines 95-96].

The word "Cataian" is an exoethnonym invented by Marco Polo, a well-known traveler who called the citizens of China "Katays" or "catays". That very word later entered into the English language and was used by Shakespeare in its characterological function. The people of China were associated at that time with the scoundrels and the word "Cataian" was an ethnophobism. For example, Page, one of the personages of the "Marry Wives of Windsor", called his compatriot Englishman a "Cataian" in the sense "a rascal/ scoundrel" (a transferred characterological ethnophobism):

Page. I will not believe such a Cataian, though the priest o'th'town commended him for a true man.

[Merry Wives of Windsor, Act II, Scene 1, lines 140-141].

This xenophobic word in modern performances, is mostly replaced by general invective units to follow the principle of political correctness.
In modern editions of the plays by Shakespeare and in the stage versions mitigation is widely used to observe the principle of political correctness including the substitutions of abusive ethnonyms, that is ethnophobisms, for the corresponding neutral ones. In this case the original is distorted but it is not the fault of Shakespeare, but of his editors.

The ethnonym "Scythian" fulfils in the plays by Shakespeare different functions. I. Azimov believes that the word "Scythians" used in Shakespeare's "King Lear" is an achronic element as Scythians are supposed to appear in the northern Black Sea region in the $7^{\text {th }} \mathrm{c}$. BC.

He says that the events described by Shakespeare are dated to the 800 BC (according to Holinshed ${ }^{1}$ ) when Scythians were hardly known in Britain (IX c. BC) [1, p. 8].

Achronic character of this ethnonym is not obvious, as many scholars believe that Scythians lived in Northern Black Sea region from 900 to $400 \mathrm{BC}$ and their existence could be known to the peoples of Northern Europe including the territory of modern Great Britain. "Scythian" is supposed to be a derivative of the endonym which came from the Iranian "skuda" which means "archer". Herodotus mentioned Scyths in his works and wrote that they settled in the northern Black Sea Region in the $7^{\text {th }}$ c. BC. Herodotus believed that the name "skud" was common for all Scythian tribes and derives from the name of their tzar.

Some scholars suppose that "skul" and "skud" are cognates with the letter "d" being replaced by the "l". But there are scholars who do not think that these words have a common origin.

It is not possible to say for certain when the word "Scythian" entered into the word-stock of the English language but we agree with Asimov that it can hardly be used on the territory of Britain in the times of King Lear. The great distance between Black Sea Regions and the isle called Great Britain was enormous and the communication between them is not supposed to be close and intensified. The appearance of this word at that time is really doubtful.

Thus, whether the word Scythian is one of Shakespeare's anachronisms or not is open for further discussions.

The ethnonym "Scythian" used by Shakespeare in his "King Lear" fulfils a characterological function. In his times Scythians associated with the bellicosity and barbarity. These nomads were known as the aggressive people attacking other tribes dislodging them from the places of their settlement in northern Black Sea regions and other territories:

King Lear. The Barbarous Scythian,

Or he that makes his generation messes

To gorge his appetite, shall to my bosom

Be as well neighbour'd, pitied, and relieved

As thou my sometime daughter.

[King Lear, Act I, Scene 1, lines 118-122].

Here King Lear reproaches his daughter Cordelia for the insufficient love for him, her father. He states that her behavior is even worse than the behavior of the barbarous Scythians, the latter word having the same meaning here as the word "savages".

In "Henry VI" (part I) Shakespeare used the ethnonym "Scyths" in its generalizing function. Here it became a common form denoting any nomad tribe (generalized superethnonym). But in

Raphael Holinshed (1529-1580) was an English chronicler. His chronicles known as Holinshed's Chronicles were one of the major sources used by W. Shakespeare for a number of his plays including "King Lear". 
reality which Shakespeare mentions it was a tribe of massaguets and this specific ethnonym would have been more exact in this case. In the play it deals with the massaguets who dislodged the Scythians from the Caspian region and settled in their territories but Shakespeare includes in the text the word "Scythian" instead of the word "massaguets":

Countess of Auvergne. The plot is laid: if all things fall out right,

I shall as famous be by this exploit

As Scythian Tomyris by Cyrus' death

[Henry VI, Part I, Act II, Scene 3, lines 4-6].

Kir (Cyrus) was a great invader who created the Persian Empire. In VI BC he appeared on the eastern coast of the Caspian Sea, which was the region where massaguets lived. In the battle with massaguets Kir suffered his first and last defeat as he was killed in this battle.

Thus, there are some inaccuracies in the playwright's version of the history which is typical of many works by Shakespeare. The audience of the XVI-XVII c. for whom Shakespeare wrote his plays hardly knew anything about massaguets while the word "Scythian" was well-known. That is why the choice in the favour of the word "Scythian" is well-grounded and explicable.

It is not always clear whether the author uses the ethononym in its nominative function (the marker of nationality, place of residence) or in the characterological one. Such is the case of the ethnonym "Florentine" when it concerns Jago. The phrase in the Shakespearean text can be treated in both ways:

Cassio. I never knew a Florentine more kind and honest.

[Othello, Act III, Scene 1, lines 42-43].

But many scholars are puzzled. Judging by the previous reference to Jago he is a Venetian. At the same time, he may be a Spaniard if to take into consideration his name and expressions which he uses (Diablo, ho!). We may suppose that being a Spaniard by origin Jago is a "Venetian" citizen as he calls Venice his country:

Jago. I know our country disposition well

In Venice they do let heaven see the pranks

They dare not show their husbands; $<\ldots .>$

[Othello, Act III, Scene 3, lines 202-204].

Some scholars believe that Shakespeare forgot about the national identification of Jago calling him in different episodes either a Venetian or a Florentine. The other investigators think that it is a result of editor's bad corrections. Most probably that when Cassio calls Jago a Florentine he does not mean his nationality but his moral qualities.

As to Casio himself he is a real Florentine. This reference is used as indication of his ethnic identification (demonym). At the same time Jago perfidiously praised him:

Jago. And what was he? Forsooth,

a great arithmetician,

One Michael Cassio, a Florentine

[Othello, Act I, Scene I, lines 19-20].

As one can see, this demonym suggests both nationality and doubtful praises (axiological meaning). "Florentines" were known for their politeness and good manners. As a real Florentine Cassio is a noble man, gentle and polite. As a citizen of Florence he fully answers the stereotype of the Florentine people. But Jago implies that all these qualities are not suitable for a good soldier who must be severe. No wonder that Cassio who sees the world through rose-coloured spectacles could call Jago also a Florentine using the word not in its primary meaning but in its positive axiological one.
The words "Theban" and "Athenian" fulfil in "The King Lear" characterological function. In the times of Shakespeare, the citizens of Thebes - Thebans associated with a high degree of learning. This city demonym was an equivalent of the word "philosopher". Thebes were known for the high level of erudition of its citizens. No wonder that showing his great respect for the interlocutor Lear addresses him using the word "Theban":

Lear. I'll take a word with the same

learned Theban.

[King Lear, Act III, Scene 4, lines 160-161].

For the citizens of Aphenes who believed that their northwestern neighbours - Thebans were dull-witted, such a comparison of Thebans with clever people would have been a shock.

Later instead of the word "Theban" Lear uses the more correct (from the historical point of view) word "Athenians" as the citizens of this particular city were known to be real philosophers. When addressing the beggar, he expresses his respect (for him) calling him Athenian:

Lear. Come, good Athenian

[King Lear, Act III, Scene 4, line 173].

During the whole century after Shakespeare's death science (philosophy) was associated with the ancient Greeks. These associations were understandable by the audience of the Elizabethan period (XVI-XVII c.) when Shakespeare created his masterpieces.

Conclusions. If to summarize the observations one should draw the following conclusions:

1. Shakespeare widely used different kinds of ethnonyms: official (primary) and non-official (secondary).

2. Among the non-official ethnonyms dominant ones are ethnophobisms (87\%).

3. The ethnonyms in Shakespeare's plays fulfil two main functions: the ethnic identification function and the charactorological one. The latter is mostly based on the national stereotypes formed for centuries.

4. Shakespeare uses a lot of anachronic ethnonyms. This trend corresponds to his general conception concerning a temporal and local structure of the plays: Shakespeare is well known for his free compositional arrangement of time and place.

5. In many cases Shakespeare modernized the events "carrying over" the representatives of some ethnic groups to the ancient times when they did not exist.

The artistic ethnonymic field of Shakespeare required further deep investigation. The comparison of ethnonymic variants in different folios and modern editions will allow to distinguish between the original versions of Shakespeare and corrections made by his editors.

\section{References:}

1. Azimov A. Shakespeare Guide. English plays. Translated from English by E.A. Katz. Cenropoligraf, 2007 [in Russian].

2. Murzin V.Yu. \& others. Scythia: history, economy, life, religion, art, military. Nikolaev : Vozmozhnosti Kimmenij, 2004. [in Russian].

3. Barth F. (ed.). Ethnic Groups and Boundaries: The Social organization of Cultural Difference. Waveland Press, 1998.

4. Alieva L.A. and Petrenko V.F. "The study of ethnic stereotypes with a help of technique of "multiple identifications"." Psychological journal, No. 6 (1987). Pp. 21-33 [in Russian].

5. Hamilton D.L., and Sherman J.W. Stereotypes. / In R. S. Wyer, Jr. \& T. K. Srull (Eds.), Handbook of social cognition: Basic processes; Applications, 1994. Pp. 1-68. Hillsdale, New Jersey, US : Lawrence Erlbaum Associates, Inc. 
6. Vahtin N.B and Golovko E.V. Sociolinguistics and sociology of language. Saint Petersburg : Humanitarian Academy, 2004 [in Russian].

7. Stepanov V.V. and Susokolov A.A. "Ethnos and its environment." Human, No. 6. 1990. Pp. 51-59 [in Russian].

8. Jenkins R. "Ethnicity: Identity Categorization and Power." Ethnic and Racial Studies. Vol. 17. Vol. 2., 1994. Pp. 197-223.

9. The Complete Works of William Shakespeare. Oxford : the Shakespeare Head Press. Wordsworth Edition Limited, 2007.

10. Kobozeva I.M. Linguistic semantics. Moscow : URSS, 2004 [in Russian].

11. Mizetska V.Ya. Anachronisms in Shakespeare's Drama. Odessa Linguistic Journal, No. 2 (2013). Pp. 68-75 [in Russian].

Мізецька В. Я., Ладиненко А. П. Етноніми у п’'сах Вільяма Шекспіра

Анотація. Стаття присвячена дослідженню вживання етнонімів у п’єсах Шекспіра. Ілюстративний матеріал дослідження: «Цимбелін», «Гамлет», «Генріх VI (частина I)», «Король Лір», «Отелло», «Веселі дружини Віндзора», що представлені у формі, поданій у колекції Вордсворта (2007). Пояснюється, що етноніми - це слова, що вказують на національність та належність до етносів різного розміру та різних місць розселення. Пропонується згрупувати етноніми в первинні етноніми - офіційні назви, встановлені в міжнародній та лінгвістичній практиці, та вторинні неофіційні назви етнічних груп та об'єднань.

Шекспір не схильний вигадувати етноніми, він черпає ix із наявного запасу слів. Етнофобізми він використовує здебільшого у сценах, де, ймовірно, можуть виникати конфлікти. Щодо вторинних етнонімів можна стверджувати, що у п’ссах Шекспіра переважають пейоративні одиниці етнофобізмів. Шекспір використовує як офіційні, так і неофіційні етноніми, що позначають представників великих етнічних груп (рас, націй) та малих етнічних груп, включаючи жителів міст і селищ (демоніми). Етноніми у п'єсах Шекспіра виконують дві основні функції: здебільшого вони є показниками етнічної ідентифікації особистості, а в інших випадках вони характеризують персонажів завдяки національним стереотипам. Зазначається, що Шекспір не завжди зрозуміло використовує етнонім у його номінативній функції (маркер національності) чи в характерологічній. Такий випадок 3 етнонімом «флорентійський», коли він стосується Яго (Отелло). До фрази "I never knew a Florentine more kind and honest" можна поставитись неоднозначно.

Дослідження показує, що Шекспір не був точним у виборі етнонімів, тому в його п'єсах багато анахронізмів. Наприклад, за часів Ліра, описаного Шекспіром, етноніма "Englishman" не існувало. Насправді Шекспір не винен, оскільки деякі редактори та режисери замінили його "British man" словом "Englishman". Етнічні анахронізми можна знайти в його «Цимбеліні». Одного 3 персонажів позначають як "Frenchman". За часів «Цимбеліна» Франція як держава не існувала. Дослідження показало, що здебільшого Шекспір модернізував події та переніс представників деяких груп у давні часи, коли їх не було.

Художня етнонімічна сфера Шекспіра вимагає подальших глибоких досліджень. Порівняння етнонімічних варіантів у різних фоліо та сучасних виданнях дозволить розрізнити оригінальні версії Шекспіра та виправлення, внесені редакцією.

Ключові слова: демонім, ендоетнонім, етнічний анахронізм, етнонім, етнофобізм, екзоетнонім, Вільям Шекспір. 